\title{
A Europe without Digital Borders: Beyond the Reach of Antitrust?
}

On 10 May 2017, the European Commission published its final report on the e-commerce sector inquiry as well as a mid-term review on the implementation of its Digital Single Market Strategy. The concurrent publication of both documents exemplifies the close coordination between the Commission's regulatory agenda in this area and DG Competition's enforcement priorities.

As we have witnessed with past sector inquiries, the Commission will use the results of the e-commerce sector inquiry to target its antitrust enforcement efforts. In February 2017, the Commission already opened three investigations into e-commerce markets (consumer electronics, video games and hotel accommodations) tackling retail price restrictions and discrimination on the basis of location and geo-blocking. More recently, it announced an investigation into the distribution agreements and practices of clothing manufacturer and retailer Guess, suspecting it restricts retailers from making unsolicited cross-border sales. Vertical restraints are (literally) back in fashion.

At least to some extent, the necessarily limited number of high-profile investigations at the EU level will have a general deterrence effect. According to the press release accompanying the final report, the sector inquiry itself already prompted companies in the clothing industry and other retail sectors to review their commercial practices.

Antitrust enforcement will not bring about a sea of change for e-commerce in consumer goods however. The results of the sector inquiry confirm that limitations on cross-border sales are most often unrelated to contractual or other arrangements with suppliers, but result from a business decision of the retailer. There are a variety of commercial reasons why retailers decide not to expand the geographic scope of their activities to other Member States, such as costs and efforts related to the translation of the website, marketing and delivery and return handling. At our CoRe Symposium Competition Law and Regulation: Boosting E-commerce in the EU's Digital Economy, which took place in Brussels on 12 May, industry representatives further identified the lack of harmonisation of consumer protection laws as a key barrier to engage in targeted sales cross-border. Meaningful progress towards the ambitious aim of boosting e-commerce across the EU will therefore depend on the combined effect of the legislative proposals on geo-blocking, cross-border parcel delivery, simpler VAT declaration procedures and digital contract rules - yet only when coupled with effective public enforcement.

Regarding the online distribution of digital content, where the interplay between IP rights and competition law poses an additional complicating factor, the real added value of antitrust enforcement is even more difficult to see. Let us take the Cross-border access to pay-TV case as an example. In July 2015, the Commission issued a Statement 
of Objections to Sky UK and six major US film studios, setting out the preliminary view that certain clauses in their film licensing contracts violate Article 101 TFEU. The clauses prevent Sky UK from making passive sales to consumers outside of the territory covered by its license and require the rights holders (film studios) to prohibit other EEA pay-TV operators from making passive sales in the UK and Ireland. The Commission considers these provisions to be 'additional obligations' within the meaning of the Court of Justice's Premier League/Murphy judgment, ${ }^{1}$ designed to eliminate cross-border competition between pay-TV broadcasters and grant absolute territorial exclusivity to the rights holders. The decision to accept commitments from Paramount Pictures reveals that the Commission not only targets the clauses in relation to satellite transmission, but also in relation to online transmission (in the context of a broader pay-TV licence agreement). ${ }^{2}$ Yet the prevailing view, also expressed by Pablo Ibáñez Colomo (Associate Professor of Law, LSE) at our CoRe Symposium, is that there is no exhaustion of the right of communication to the public in relation to the online transmission of copyright-protected content. Assuming that the 'country of origin' principle indeed applies to online transmissions, it is unclear what the removal of the contractual obligations on Sky UK to geo-block its online pay-TV service to customers located outside of its exclusive territory would achieve in practice. Under national copyright law, a content provider would still need specific authorisation from the licensee in relation to each territory in which the copyright-protected content is communicated to the public. So unless accompanied by a reform of copyright law at EU level, the remedial action will enable consumers to request access to foreign satellite pay-TV services, but will have little or no impact for cross-border access to online pay-TV services.

In addition, it is important to bear in mind that the territorial partitioning of the European audiovisual market is not (only) a result of copyright protection. Rights to audiovisual content, and in particular premium content, are predominantly licensed territory-by-territory or by linguistic area (and through separate tender processes held at different times) because this enables the rights holders to extract the highest possible value. As the Commission acknowledges in its decisional practice, ${ }^{3}$ it is unlikely that rights holders would deviate from their current preferred model of licensing unless there is a sound business case for it. The same holds true for the vast majority of content providers. According to the sector inquiry, most digital content providers responded that purchasing content for territories in which they are not yet active, to the extent available, would not be cost-efficient. One may therefore wonder what type of crossborder competition is actually being eliminated.

DG Competition will always have to contribute to the overarching ambitions of the EU by targeting its enforcement actions to certain priority sectors and areas. And in the past, strategic antitrust enforcement action addressing, for instance, airport charges,

\footnotetext{
Joined Cases C-403/08 and C-429/08 Football Association Premier League Ltd and Others v QC Leisure and Others and Karen Murphy v Media Protection Services Ltd (2011) ECLI:EU:C:2011:631.

2 Cross-border access to pay-TV (Case AT.40023) Commission Decision 2016/C 473/04 [2016] OJ C437/5.

See eg, BSkyB/Sky Deutschland/Sky Italia (Case M.7332) Commission Decision 2015/C 58/01 [2015] OJ C58/1.
} 
roaming charges and interchange fees for credit and debit cards, eventually led to a more comprehensive regulatory solution. Perhaps the Cross-border access to pay-TV case should be seen as a first step in that direction. For the time being, however, the gap with regulatory efforts, also considering the notable exclusion of audiovisual services from the geo-blocking regulation, remains unabridged.

As discussed, there is a much closer alignment between antitrust enforcement and the regulatory initiatives prompted by the Digital Single Market Strategy in the context of e-commerce in consumer goods - even to the extent that the complementary role that antitrust can play appears rather minimal. After all, in terms of active sales, the most competition law can offer is giving non-dominant retailers the commercial freedom to decide whether to serve foreign customers cross-border and online. I doubt that this will catalyse business take-up of cross-border e-commerce opportunities in Europe to the extent the Commission aspires.

Questions about the role and function of EU competition law enforcement and/or sector-specific regulation in shaping market dynamics and achieving certain policy objectives are also at the core (pardon the pun) of several contributions in this issue. In Law in Action in the Private Security Industry, Glenn Scheerlinck, Caroline Buts, Genserik Reniers and Marc Cools assess how and to what extent different national regulatory frameworks impact competition in the private security sector. Carole Mackzovics scrutinises the main novelties brought about by the new fourth railway package, designed to remove remaining barriers to the creation of a genuine, competitive Single European Railway Area. Against the backdrop of increased calls for several Member States to adopt a more protectionist industrial policy, David Reader examines the scope for public interest considerations to be taken into account under the EU merger control regime. And in Caution Ahead: High and Unpredictable Fines for Gun Jumping, Robert Klotz, co-editor of this journal, and Caroline Ruiz Palmer discuss the growing trend of competition authorities imposing heavy fines on parties for implementing a transaction prior to merger approval.

The Reports section of this issue offers an insightful overview of important competition law and regulatory law developments in Austria, France, Greece, Hungary, Italy and the United Kingdom. We also have two case notes, commenting on an Advisory Opinion of the EFTA Court concerning the applicable test to determine whether a joint bid for a public contract constitutes a restriction of competition by object and on the General Court's recent judgment in the Greek Lignite case.

As a final announcement, we are proud that Andriani Kalintiri (LSE Fellow) has joined our editorial team as the Book Reviews Editor.

We hope you will enjoy reading CoRe's second issue! 